


\section{About IJMA [last updated October, $\left.1^{\text {st }}, 2021\right]$}

$\checkmark$ International Journal of Medical Arts is the Official Journal of the Damietta Faculty of Medicine, AlAzhar University, Egypt

$\checkmark$ It is an International, Open Access, Double-blind, Peer-reviewed Journal

$\checkmark$ Published four times a year

$\checkmark$ The First Issue was published in July 2019

$\checkmark$ Published under the following license: Creative Commons Attribution-ShareAlike 4.0 International Public License (CC BY-SA 4.0). It had updated from the Creative Commons license [CC BY] in volume 2, Issue 4, October 2020 About IJMA

$\checkmark$ The Egyptian Knowledge Bank hosts the web site of IJMA

$\checkmark$ The Egyptian Knowledge Bank supports IJMA

$\checkmark$ IJMA follows the regulations of the International Committee of Medical Journal Editors

$\checkmark$ IJMA is indexed in the "Directory of Open Access Journals" [15 January 2021].

$\checkmark$ IJMA is indexed in J-Gate [29-6-2021]

$\checkmark$ IJMA is a member of the International Society of Managing and Technical Editors

$\checkmark$ Listed in "Index Copernicus", "Publons", "Academic resource index [ResearchBib]" "Electronics journal library", "Eurasian Scientific Journal Index", "WorldCat" Superstar Journal Database, and "Citefactor"

$\checkmark$ IJMA introduced to the search engine [BASE] through DOAJ

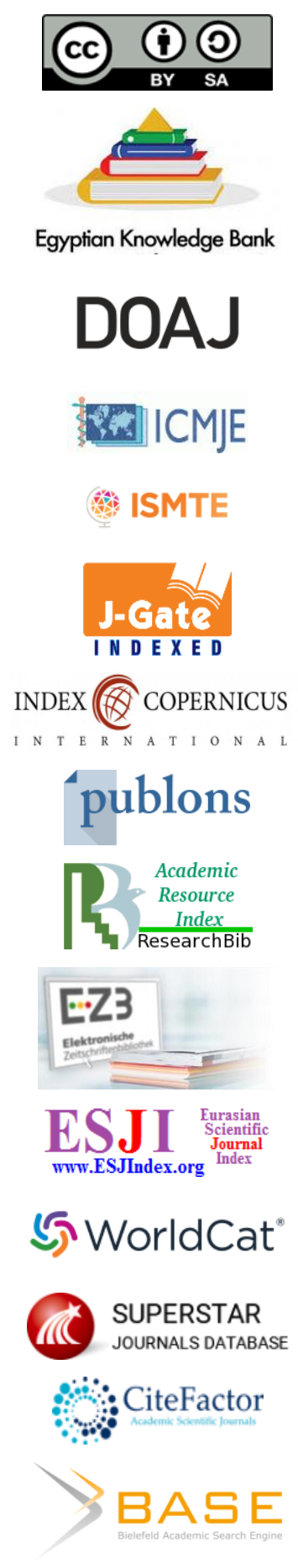




Available online at Journal Website
https://ijma.journals.ekb.eg/
Main subject [Public Health]

Original Article

\title{
Predictors of Asthmatic Children's Quality of Life in Damietta Governorate, Egypt
}

\author{
Ahmed M. Yousef [1], Mohamed El-Hady Imam [2], Ayman Ahmed Mahmmoud [1], Atef Wahdan Alrifai [3]
}

\author{
1 Department of Public Health and Community Medicine, Damietta Faculty of Medicine, Al-Azhar University, Egypt \\ 2 Department of Public Health and Community Medicine, Faculty of Medicine for boys, Al-Azhar University, Cairo ,Egypt \\ ${ }^{3}$ Department of Chest Diseases, Damietta Faculty of Medicine, Al-Azhar University, Egypt \\ Corresponding author: Ahmed M. Yousef \\ Email: ahmed.mayousef@domazhermedicine.edu.eg
}

Submission date: August 26, 2021; Acceptance date: September 13, 2021

DOI: 10.21608//JMA.2021.92801.1358

\section{ABSTRACT}

Background: Bronchial asthma is the most prevalent illness among children and teenagers. It is considered a major cause of morbidity. The physical, social, and psychological domains of childhood asthma are all affected.

Aim of the work: To measure the pediatric asthma quality of life [PAQOL] levels within asthmatic children and its main predictors in Damietta, Egypt.

Methods: An analytical cross-sectional survey was carried out utilizing a questionnaire that assesses [PAQOL] levels with related socio-demographic factors and asthma control levels. Asthma control level was tested by an asthma control test questionnaire. PAQLQ as a dependent variable and other plausible independent variables were analyzed by a stepwise linear regression model.

Results: Two hundred participants, aged 7-17 years were included; [56\%] were females, [30.5\%] residing in urban areas, and [77\%] had belonged to middle and low socioeconomic classes. Gastro-esophageal reflux [GER] was shown to have a significant positive correlation with allergic rhinitis $[P<0.01]$ and obesity $[P<0.01]$. Otherwise, GER was shown to be negatively correlated with asthma control status $[\mathrm{P}<0.01]$. Mean \pm standard deviation $[S D]$ of overall, activity and Emotion domains scores of QOL were $4.51 \pm 1.3,4.52 \pm 1.25$, and $4.54 \pm 1.39$ respectively. While more than $50 \%$ of the symptoms domain scores were more than 4.7. Low socioeconomic level $[P<0.01]$, poor asthma control $[P<0.01]$, and positive history for controller medications $[P<0.05]$ were significant predictors for lower asthmatic children's quality of life.

Conclusion: Asthmatic children tend to have a poorer quality of life. To provide effective asthma treatment to the general public, prescribers and patients must both understand and be educated. Healthcare providers should consider PAQOL with greater attention to children with poor socio-economic standards and uncontrolled asthma in the management plan.

Keywords: Pediatric asthma; Quality of Life; Asthma control; Socioeconomic level.

This is an open-access article registered under the Creative Commons, ShareAlike 4.0 International license [CC BY-SA 4.0] [https://creativecommons.org/licenses/by-sa/4.0/legalcode.

Citation: Yousef AM, Imam ME, Mahmmoud AA, Alrifai AW. Predictors of Asthmatic Children's Quality of Life in Damietta Governorate, Egypt. IJMA 2021; 3 [4] OctoberDecember: 1818-1826 [DOI: 10.21608/IJMA.2021.92801.1358].

${ }^{*}$ Main subject and any subcategories have been classified according to the research topic 


\section{INTRODUCTION}

Bronchial asthma is one of the most common diseases that affect the airways. About a thousand people die from asthma every day, and the number of individuals affected by the disease is growing [1]. Asthma forms a major co-morbid illness and a chronic inflammatory process affecting the airways associated with broncho-constriction complicated by airflow obstruction [2]. It is manifested by wheeze and repeated episodes of breathlessness whereas chest tightness and dyspnea are other manifestations of asthma [3]. It is a public health concern in all nations that is not primarily connected to the country's degree of development [4]. Asthma is putting a growing strain on governments, healthcare systems, families, and patients all across the world. Prevalence always widely varying between countries and within every single country, and has been increasing with the presence of an allergy, as modern lifestyles are adopted and communities become more urbanized, that trend will continue over the next two decades ${ }^{[1]}$. Variations in asthma prevalence between countries may be related to differences in climate, socioeconomic status, air pollution, lifestyle, and exposure to respiratory illness, as well as allergen level fluctuation [5].

Bronchial asthma is widespread in Egypt, and Children from poor socioeconomic categories are more likely to have undiagnosed or untreated bronchial asthma [6]. In Egypt, asthma prevalence was reported to be $7.7 \%$ in children less than 15 years old $[7]$.

Quality of life [QOL] has many definitions, most suitable definition for it regarding our study is Gotay's definition who define it as [a state of well-being that is made up of two portions: [1] The capability to execute daily tasks in a way that reflects one's physical, psychological, and social well-being, and [2] Patient satisfaction with functional levels and the control of sickness and/or treatment-related complications [8]. When children suffer from asthma, not only their physical health is affected, but also their psychological and social health ${ }^{9}$. Aside from interrupting their sleep and making them weary, asthma affects children's daily lives by restricting their activities. As a result, individuals suffer dread, wrath, grief, frustration and the inability to engage in normal activities. Children with these attitudes have a worse quality of life than healthy children [10]. The quality of life can be affected by a variety of factors. Also, life events play a significant influence in improving QOL [11]. Children with asthma's quality of life are affected by a variety of factors, including Sociodemographic, illness severity, and asthma management practices [12].

Pediatric Asthma Quality of Life Questionnaire [PAQLQ], the most often used questionnaire, was developed and validated by Juniper et al. ${ }^{[13]}$ in 1996. It measures vital areas of function for asthmatics, including physical and emotional function. Reproducibility occurs when the clinical state is stable and responsive to small changes. Because the PAQLQ is a sensitive instrument, it can capture the influence of a therapeutic intervention ${ }^{[14]}$

A major public health concern, pediatric asthma's prevalence and costs to the healthcare system continue to grow. It is still unknown what causes asthma and allergies despite considerable studies. The literature shows that the Health-Related Quality of Life [HRQOL] in children with asthma are related to both disease and non-disease factors, according to a number of studies $[7,12,14]$. These relations will be better understood to be able to achieve new treatments that can help Egyptian children with asthma.

\section{AIM OF THE WORK}

Allergic diseases represent a proportion of residents of the province of Damietta, and there are many factories and workshops that may in one way or another affect children's chest allergies. No further research in this topic after literature review was done in such setting. So, we aimed, through this survey, to measure the pediatric asthma quality of life (PAQOL) levels among asthmatic children and to assess the prediction effect of their socio-demographic criteria, morbidity history, asthma control level and medications they use on their (PAQOL) levels in Damietta governorate, Egypt.

\section{PATIENTS AND METHODS}

\section{Study setting, design, and participants}

In this study, asthmatic children aged 7 to 17 were recruited from Al-Azhar University Hospital in New Damietta and the outpatient clinic at the Damietta Chest Hospital to participate in a cross-sectional study.

Inclusion criteria: [Age 7-17 years, physician-diagnosed asthma for at least 1-year, willing to participate in the study].

Exclusion criteria: [Unwilling to participate in the study "patient or parents", cardiac co-morbidities result in significant hemodynamic changes, respiratory diseases need treatment with antibiotics, the mental condition makes it impossible to perform an interview, suffering from other chronic diseases such as diabetes...etc.]

\section{Sampling}

Sampling Technique: A systematic random sampling methodology was used to conduct our study. In each hospital, we selected a child randomly $[1,4,7$, and $10 . . . e t c$.$] . All$ attendants who agree with the inclusion requirements were hired before the target sample size is met.

Sample size calculation: To estimate the sample size, we used the power and sample size program version 3 based 
on: The mean QOL score in Egyptian asthmatic children was found to be 4.1 with a standard deviation [SD] of 1.0 [7]. Precision 2\%, 95\% confidence level, study power $80 \%$. The minimum sample size should be at least 198.

\section{Study variables}

Dependent variable [primary outcome]: Pediatric asthma quality of life score.

Independent variables [predictors]: level of asthma control, asthma management history, and socio-demographic criteria [including age, sex, residence, socioeconomic status, paternal consanguinity, family history of asthma and smoking exposure].

Survey tools of data collection: Data were gathered using an interviewing questionnaire sheet for each child containing:

1- Clinical evaluation: patients were assessed according to the following points of interest: [Medical history and examination, including past, present, and family risk factor history]. Pediatric and pulmonology doctors did their extreme efforts to help picking up the asthmatic children according to the physician-diagnosed asthma criteria.

2- Socioeconomic status [SES]: obtained through five parameters. The scores of all parameters were classified into three socioeconomic levels [13]: High SES level; those with scores from 11 to 14, Middle SES level; those with scores from 8 to 10, Low SES level; those with scores below 8 .

3- Asthma control test [ACT]: is a tool that analyses asthma symptoms, the degree of shortness of breath, and the impact of asthma on the child's daily routine activities. It was divided into two categories: controlled and uncontrolled. The score goes from 0 [worst] to 27 [best] asthma controls. A cutoff point of 19 was used to define uncontrolled asthma [16]. It was reported by both the child and/or his/her caregiver.

4- The Arabic version of the interviewer administrated pediatric asthma quality of life questionnaire [PAQLQ]: It assesses the functional [social, emotional, and symptom] issues that are the most bothersome for asthmatic children [7-17 years]. PAQLQ consists of 23 questions divided into three areas [activity limitation, symptoms, and emotional function]. The PAQLQ has a time limit of two weeks [17]. It has been demonstrated that children as young as seven years old can answer the questionnaire and understand the items accurately ${ }^{[18]}$. All items were evaluated on a seven-point Likert scale, with one indicating complete impairment and seven indicating no impairment. Individual items in the PAQLQ would be equally weighted. The cumulative QoL score was calculated using the total of all items rather than the domain average [19]. Victoria Sayer and Jilly Styles emailed the Arabic version of PAQLQ to us [Personal
Assistants to Prof. E. Juniper, McMaster University Canada].

Ethical approval: It was obtained from Institutional Review Board at Damietta Faculty of Medicine, Al-Azhar University [IRB\# 00012367-19-09-007; 15/9/2019]. An informed consent from anonymous participants was added as an initial page of the questionnaire before their survey started with emphasis on voluntary participation and withdrawal at any time without any justification.

Statistical analysis: It was carried out by using the statistical package for the social sciences [SPSS, version 23; SPSS Inc., Chicago, Illinois, USA] [using an IBM personal computer]. Frequency, percentage, mean and standard deviation were used as descriptive statistics. For comparison between groups, chi-square and t-tests were used for qualitative and quantitative variables respectively. ANOVA with post hoc LSD was used for comparison between more than two quantitative groups. A multivariate study using linear regression was performed to determine the major predictors of QoL in asthmatic children. When the P value was less than 0.05 , the differences were judged statistically significant.

\section{RESULTS}

Characteristics of Socio-demographic groups and asthma history: The study included 200 surveyed children fulfilling the inclusion criteria; their age ranged from 7 to 17 years old. Nearly half [56\%] of them were females, with onethird [30.5\%] residing in urban areas. The majority of caregivers [64\%] had a middle socioeconomic status. Furthermore, [64\%] of our children lived in rooms with crowding index less than or equal to two people, and about [54\%] of them had fewer than five family members [Table 1].

Figure $[1 \mathrm{~A}]$ showed that almost more than three-quarters [83\%] of them had allergic rhinitis. Although near to half [54.5\%] of them have a positive family history of asthma. Also, one-third [37\%] of them had been exposed to smoking. A minority [13\%] and [22\%], respectively of them have a history of obesity and Gastro-esophageal reflux as comorbid disorders. Figure [1B] showed that, in between attacks; the majority of them [69.5\%] were taking controller prescriptions and the main controller methods were B2 agonist [33\%] and ICS [32.5\%]. The asthma control test revealed that threequarters [76.5\%] of the children enrolled in the study had uncontrolled asthma.

Relationship between asthma control status and other potential attack precipitators: Table [2] revealed a strong positive correlation was discovered between patients who reported a family history of asthma and allergic rhinitis as well as obesity. Gastro-esophageal reflux [GER] was shown to have a significant positive correlation with allergic rhinitis and obesity. Otherwise, GER was shown to be negatively 
correlated with asthma control status. The status of asthma control was found to have a clear positive correlation with total pediatric Quality of life [PQOL] scores.

Asthma-related and socio-demographic factors affecting asthma quality of life: Our results showed that the mean \pm standard deviation [SD] of overall, activity and emotion domains scores of QOL were 4.51 $\pm 1.3,4.52 \pm 1.25$, and $4.54 \pm 1.39$ respectively. While more than $50 \%$ of the symptoms domain scores were more than 4.7 .

Table [3] revealed that patients whose families had low socioeconomic status [SES] reported lower scores of total overall and activity QOL domains than middle and high SES levels. It also revealed that the mean $\pm S D$ score of total PAQLQ among asthmatic children who didn't use any inhalers was $4.68 \pm 1.26$ compared to children who used more than one inhaler $4.02 \pm 1.19$ with a significant statistical difference. In the same context, patients who used more inhalers or for a longer period of time had non-significantly higher activity domain of PAQLQ scores than those who used fewer inhalers or for a shorter period of time. Symptoms domain of PAQLQ scores were substantially higher in urban asthmatic children than in rural asthmatic children. Furthermore, asthmatic children with low socioeconomic status had lower Symptoms domain of PAQLQ scores than those with middle and high socioeconomic status. On the other hand; total overall, activity and Symptoms QOL domains scores showed no statistically significant difference in their age, sex, or residence.

Another results in Table [3] showed that mean \pm SD of the emotion domain of PAQLQ scores was $4.06 \pm 1.29$ and 4.72 \pm 1.32 for children who used more than one inhaler and those who did not use any inhalers. Aside from that, no statistically significant difference was observed between asthmatic children's emotion domain of PAQLQ scores in terms of devise use and length of inhaler use. Our results also clarified that, neither the use of inhalation devices nor the length of inhaler use made a significant difference in the symptoms domain of PAQLQ scores of the study children. However, the greater the number of inhalers used, the lower the PAQLQ scores for symptoms domain.

Predictors of pediatric asthma quality of life: Table [4] showed the stepwise linear regression analysis of the possible predictors of PAQLQ as a dependent variable and other possible independent predictors. Low socioeconomic level, poor asthma control and positive history for controller medications were significant predictors for lower asthmatic children quality of life.

Table [1]: Socio-demographic characteristics of the study participants

\begin{tabular}{|c|c|c|c|}
\hline \multicolumn{2}{|l|}{ Characteristics } & Sample [n=200] & Percentage [100\%] \\
\hline \multirow[t]{4}{*}{ Age [years] } & 7- & 106 & 53.0 \\
\hline & $10-$ & 28 & 14.0 \\
\hline & $13-17$ & 66 & 33.0 \\
\hline & $\begin{array}{l}\text { Mean } \pm \text { SD } \\
\text { Range }\end{array}$ & \multicolumn{2}{|c|}{$\begin{array}{c}11.25 \pm 3.86 \\
7-17\end{array}$} \\
\hline Sex & $\begin{array}{l}\text { Male } \\
\text { Female }\end{array}$ & $\begin{array}{c}88 \\
112\end{array}$ & $\begin{array}{l}44.0 \\
56.0\end{array}$ \\
\hline Residence & $\begin{array}{l}\text { Urban } \\
\text { Rural }\end{array}$ & $\begin{array}{c}61 \\
139\end{array}$ & $\begin{array}{l}30.5 \\
69.5\end{array}$ \\
\hline \multicolumn{4}{|l|}{ Socioeconomic Status variables } \\
\hline 1- Occupation [Caregiver] & $\begin{array}{l}\text { Not working } \\
\text { Worker [manual- farmer] } \\
\text { Employee/ professional/private }\end{array}$ & $\begin{array}{c}31 \\
66 \\
103\end{array}$ & $\begin{array}{l}15.5 \\
33.0 \\
51.5\end{array}$ \\
\hline 2- Education [Caregiver] & $\begin{array}{l}\text { Illiterate } \\
\text { Read \& write } \\
\text { Basic } \\
\text { Secondary or High } \\
\text { Graduate }\end{array}$ & $\begin{array}{c}0 \\
21 \\
10 \\
60 \\
109\end{array}$ & $\begin{array}{c}0.0 \\
10.5 \\
5.0 \\
30.0 \\
54.5 \\
\end{array}$ \\
\hline 3- Family Size & $\begin{array}{l}<5 \text { members } \\
\geq 5 \text { members }\end{array}$ & $\begin{array}{c}108 \\
92\end{array}$ & $\begin{array}{l}54.0 \\
46.0\end{array}$ \\
\hline 4- Family Income & $\begin{array}{l}\text { In debt } \\
\text { Just meet routine expenses } \\
\text { Meet routine expenses and emergencies } \\
\text { Able to save/invest money }\end{array}$ & $\begin{array}{c}5 \\
42 \\
81 \\
72\end{array}$ & $\begin{array}{c}2.5 \\
21.0 \\
40.5 \\
36.0\end{array}$ \\
\hline 5- Crowdness of The House & $\begin{array}{l}\leq 2 \text { persons/room } \\
>2 \text { persons/room }\end{array}$ & $\begin{array}{c}128 \\
72\end{array}$ & $\begin{array}{l}64.0 \\
36.0\end{array}$ \\
\hline Socioeconomic Status [SES] Score & $\begin{array}{l}\text { Low } \\
\text { Middle } \\
\text { High }\end{array}$ & $\begin{array}{c}26 \\
128 \\
46\end{array}$ & $\begin{array}{l}13.0 \\
64.0 \\
23.0\end{array}$ \\
\hline
\end{tabular}


Table [2]: Correlation between Asthma Control test [ACT] Scores, Quality of life scores and asthma co-precipitators among study participants

\begin{tabular}{|c|c|c|c|c|c|c|c|c|c|}
\hline & $\begin{array}{l}\text { Smoking } \\
\text { Exposure }\end{array}$ & Consanguinity & $\begin{array}{c}\text { Family } \\
\text { history of } \\
\text { Asthma }\end{array}$ & $\begin{array}{c}\text { Atopic } \\
\text { dermatitis }\end{array}$ & $\begin{array}{l}\text { Gastro- } \\
\text { esophageal } \\
\text { reflux }\end{array}$ & $\begin{array}{l}\text { Allergic } \\
\text { rhinitis }\end{array}$ & Obesity & $\begin{array}{l}\text { ACT } \\
\text { score }\end{array}$ & $\begin{array}{l}\text { Overall } \\
\text { QOL } \\
\text { scores }\end{array}$ \\
\hline $\begin{array}{l}\text { Smoking } \\
\text { Exposure }\end{array}$ & 1 & & & & & & & & \\
\hline Consanguinity & 0.128 & 1 & & & & & & & \\
\hline $\begin{array}{l}\text { Family history of } \\
\text { asthma }\end{array}$ & $0.160^{*}$ & $0.321^{* *}$ & 1 & & & & & & \\
\hline Atopic dermatitis & $0.215^{* *}$ & 0.114 & -0.093 & 1 & & & & & \\
\hline $\begin{array}{c}\text { Gastro- } \\
\text { osphogeal reflux }\end{array}$ & 0.068 & -0.110 & -0.121 & -0.090 & 1 & & & & \\
\hline Allergic rhinitis & 0.099 & $0.159^{*}$ & $0.255^{\star *}$ & 0.069 & $0.240^{* *}$ & 1 & & & \\
\hline Obesity & -0.050 & -0.088 & $0.39^{* *}$ & 0.002 & $0.692^{* *}$ & $0.175^{*}$ & 1 & & \\
\hline ACT scores & 0.086 & 0.086 & $-0.23^{* *}$ & -0.125 & $0.202^{* *}$ & $0.239^{* *}$ & 0.123 & 1 & \\
\hline $\begin{array}{c}\text { Overall PAQOL } \\
\text { scores }\end{array}$ & 0.074 & -0.090 & -0.022 & 0.024 & 0.069 & 0.112 & 0.032 & $0.299^{* *}$ & 1 \\
\hline
\end{tabular}

${ }^{*}$ Correlation is significant at the 0.05 level (2-tailed)

${ }^{* *}$ Correlation is significant at the 0.01 level (2-tailed)

Table [3]: Univariate analysis of the relationship between total, domains of PAQLQ scores and its possible history predictors

\begin{tabular}{|c|c|c|c|c|c|}
\hline \multicolumn{2}{|c|}{ Characteristics [ $n=200]$} & $\begin{array}{l}\text { Total PAQLQ } \\
\text { [Mean } \pm \text { SD] }\end{array}$ & $\begin{array}{c}\text { Activity PAQLQ } \\
\text { [Mean } \pm \text { SD] }\end{array}$ & $\begin{array}{c}\text { Symptoms PAQLQ } \\
\text { Mean } \pm \text { SD] }\end{array}$ & $\begin{array}{c}\text { Emotion PAQLC } \\
{[\text { Mean } \pm \text { SD] }}\end{array}$ \\
\hline Age [years] & $\begin{array}{l}7- \\
10- \\
13-17\end{array}$ & $\begin{array}{l}4.53 \pm 1.3 \\
4.48 \pm 1.4 \\
4.48 \pm 1.4\end{array}$ & $\begin{array}{l}4.55 \pm 1.17 \\
4.77 \pm 1.07 \\
4.37 \pm 1.42\end{array}$ & $\begin{array}{l}4.47 \pm 1.32 \\
4.86 \pm 1.18 \\
4.34 \pm 1.49\end{array}$ & $\begin{array}{l}4.56 \pm 1.36 \\
4.51 \pm 1.46 \\
4.42 \pm 1.49\end{array}$ \\
\hline \multicolumn{2}{|c|}{$P$ value } & $P=0.327$ & $P=0.326$ & $P=0.239$ & $P=0.82$ \\
\hline Sex & $\begin{array}{l}\text { Male } \\
\text { Female }\end{array}$ & $\begin{array}{l}4.46 \pm 1.3 \\
4.55 \pm 1.2\end{array}$ & $\begin{array}{l}4.47 \pm 1.22 \\
4.56 \pm 1.27\end{array}$ & $\begin{array}{l}4.44 \pm 1.38 \\
4.51 \pm 1.37\end{array}$ & $\begin{array}{l}4.48 \pm 1.45 \\
4.58 \pm 1.36\end{array}$ \\
\hline \multicolumn{2}{|c|}{$P$ value } & $P=0.64$ & $P=0.61$ & $P=0.73$ & $P=0.59$ \\
\hline Residence & $\begin{array}{l}\text { Urban } \\
\text { Rural }\end{array}$ & $\begin{array}{l}4.7 \pm 1.2 \\
4.4 \pm 1.3\end{array}$ & $\begin{array}{l}4.72 \pm 1.09 \\
4.43 \pm 1.29\end{array}$ & $\begin{array}{l}4.79 \pm 1.27 \\
4.34 \pm 1.39\end{array}$ & $\begin{array}{l}4.78 \pm 1.35 \\
4.43 \pm 1.41\end{array}$ \\
\hline \multicolumn{2}{|c|}{$P$ value } & $P=0.057$ & $P=0.122$ & $P<0.05^{*}$ & $P=0.09$ \\
\hline $\begin{array}{l}\text { Socioeconomic } \\
\text { Status* }^{*}\end{array}$ & $\begin{array}{l}\text { Low } \\
\text { Middle } \\
\text { High }\end{array}$ & $\begin{array}{c}3.2 \pm 1.2^{\mathrm{ab}} \\
4.6 \pm 1.2^{\mathrm{c}} \\
4.9 \pm 1.1\end{array}$ & $\begin{array}{c}3.48 \pm 1.32^{\mathrm{ab}} \\
4.66 \pm 1.12^{\mathrm{c}} \\
4.71 \pm 1.29\end{array}$ & $\begin{array}{c}3.27 \pm 1.09^{a b} \\
4.63 \pm 1.32^{c} \\
4.77 \pm 1.34\end{array}$ & $\begin{array}{c}3.06 \pm 1.19^{a b} \\
4.65 \pm 1.33^{c} \\
5.05 \pm 1.14\end{array}$ \\
\hline \multicolumn{2}{|c|}{$P$ value } & $P<0.001^{* *}$ & $P<0.001^{* *}$ & $P<0.001^{* *}$ & $P<0.001^{* *}$ \\
\hline Asthma control & $\begin{array}{l}\text { Controlled } \\
\text { Uncontrolled }\end{array}$ & $\begin{array}{l}5.2 \pm 1.1 \\
4.3 \pm 1.3\end{array}$ & $\begin{array}{l}4.34 \pm 1.26 \\
5.09 \pm 0.99\end{array}$ & $\begin{array}{l}5.17 \pm 1.15 \\
4.27 \pm 1.36\end{array}$ & $\begin{array}{l}5.18 \pm 1.11 \\
4.34 \pm 1.42\end{array}$ \\
\hline \multicolumn{2}{|c|}{$P$ value } & $P<0.001^{* *}$ & $P<0.001^{* *}$ & $P<0.001^{* *}$ & $P<0.001^{* *}$ \\
\hline Devise usage & $\begin{array}{l}\text { Yes }[n=104] \\
\text { No }[n=96]\end{array}$ & $\begin{array}{l}4.35 \pm 1.33 \\
4.68 \pm 1.26\end{array}$ & $\begin{array}{l}4.39 \pm 1.26 \\
4.65 \pm 1.22\end{array}$ & $\begin{array}{l}4.31 \pm 1.39 \\
4.66 \pm 1.33\end{array}$ & $\begin{array}{l}4.37 \pm 1.45 \\
4.72 \pm 1.32\end{array}$ \\
\hline \multicolumn{2}{|c|}{$P$ value } & $P=0.73$ & $P=0.15$ & $P=0.07$ & $P=0.09$ \\
\hline \multicolumn{2}{|c|}{$\begin{array}{l}\text { of Don't use } \\
\text { One } \\
\text { More than one }\end{array}$} & $\begin{array}{c}4.68 \pm 1.26 x y \\
4.55 \pm 1.38^{z} \\
4.02 \pm 1.19\end{array}$ & $\begin{array}{l}4.65 \pm 1.22 \\
4.51 \pm 1.23 \\
4.21 \pm 1.31\end{array}$ & $\begin{array}{c}4.66 \pm 1.33^{x y} \\
4.57 \pm 1.44 z \\
3.89 \pm 1.19\end{array}$ & $\begin{array}{c}4.72 \pm 1.32 x y \\
4.55 \pm 1.5^{z} \\
4.06 \pm 1.29\end{array}$ \\
\hline \multicolumn{2}{|c|}{$P$ value } & $P<0.05^{*}$ & $P=0.17$ & $P<0.001^{* *}$ & $P<0.05^{*}$ \\
\hline $\begin{array}{l}\text { Duration of use } \\
\text { [Years] }\end{array}$ & $\begin{array}{l}1-2 \text { years } \\
2-4 \text { years } \\
\text { More than } 4 \text { years }\end{array}$ & $\begin{array}{l}4.44 \pm 1.25 \\
3.99 \pm 1.31 \\
4.59 \pm 1.32\end{array}$ & $\begin{array}{l}4.52 \pm 1.22 \\
4.08 \pm 1.38 \\
4.47 \pm 1.19\end{array}$ & $\begin{array}{l}4.39 \pm 1.31 \\
3.93 \pm 1.52 \\
4.63 \pm 1.38\end{array}$ & $\begin{array}{l}4.45 \pm 1.38 \\
4.01 \pm 1.61 \\
4.61 \pm 1.43\end{array}$ \\
\hline & alue & $P=0.79$ & $P=0.32$ & $P=0.21$ & $P=0.31$ \\
\hline
\end{tabular}

Using post hoc LSD; (a, b) Significant difference between (low, middle) and (low, high) classes respectively, (c) Non-significant difference between middle and high classes \& $(x)$ Non-significant difference between (Don't use and one) ( $p>0.05)(y, z)$ significant difference between (Don't use, More than one) and (One, More than one) $(p<0.05)$ categories respectively, ${ }^{*} P$-value is statistically significant $<0.05^{\star \star} P$-value is highly statistically significant $<0.001$. 
Table [4]: Stepwise linear regression analysis of total PAQLQ score as a dependent variable in control to other independent variables

\begin{tabular}{|c|c|c|c|}
\hline Independent variables & $\beta$ & $\mathrm{p}$-value & Partial correlation \\
\hline \multicolumn{4}{|l|}{ Coefficients } \\
\hline Socio Economic Status level & 0.340 & $0.000^{*}$ & 0.357 \\
\hline Asthma Control Level & 0.246 & $0.008^{*}$ & 0.263 \\
\hline History of controller medications & 0.200 & $0.030^{*}$ & 0.215 \\
\hline \multicolumn{4}{|l|}{ Excluded Variables } \\
\hline Age & -0.156 & 0.083 & -0.173 \\
\hline Sex & -0.072 & 0.452 & -0.076 \\
\hline Residence & -0.091 & 0.333 & -0.097 \\
\hline Smoking Exposure & 0.074 & 0.430 & 0.079 \\
\hline Consanguinity History & 0.049 & 0.740 & 0.033 \\
\hline Duration of illness / in years & -0.057 & 0.559 & -0.059 \\
\hline Family history & -0.146 & 0.182 & -0.134 \\
\hline Associated comorbidities: Atopic dermatitis & 0.097 & 0.356 & 0.093 \\
\hline Associated comorbidities: Gastro esophageal reflux & 0.036 & 0.701 & 0.039 \\
\hline Associated comorbidities: Allergic rhinitis & -0.016 & 0.863 & -0.017 \\
\hline Associated comorbidities: Obesity & 0.116 & 0.209 & 0.126 \\
\hline Duration of Inhalers use & -0.037 & 0.748 & -0.032 \\
\hline Asthma Duration & -0.150 & 0.094 & -0.168 \\
\hline Place of Health service & -0.042 & 0.732 & -0.034 \\
\hline Total Model Significance & $F=9.129$ & $0.000^{*}$ & \\
\hline $\mathbf{R}^{2}$ & 0.215 & & \\
\hline
\end{tabular}

${ }^{*}$ P-value is statistically significant $<0.05$

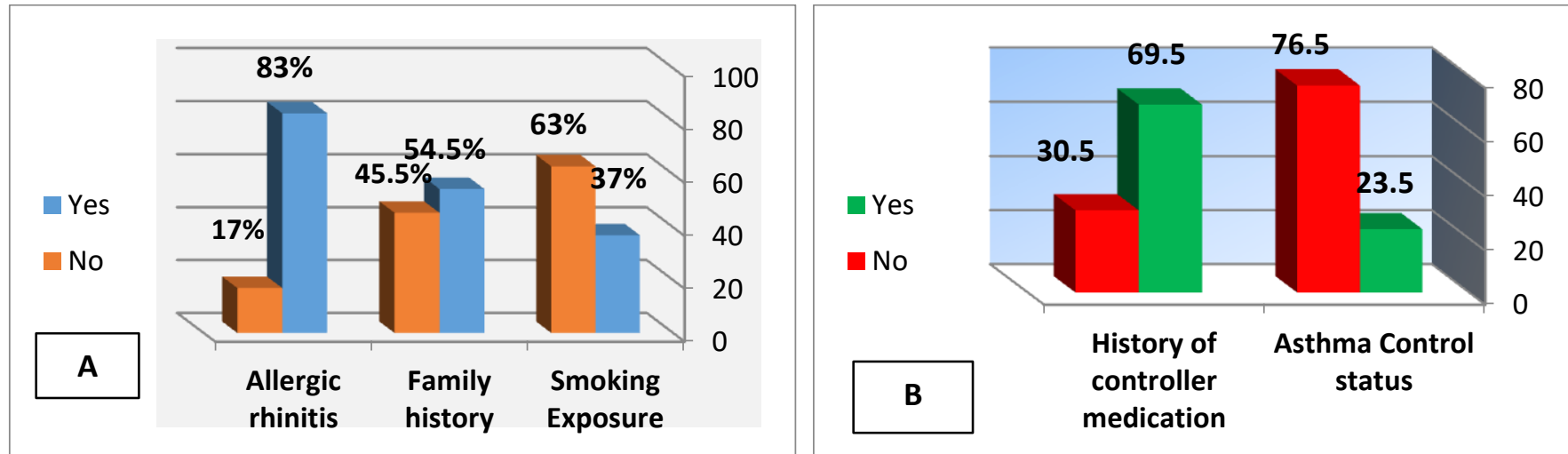

Figure [1]: [A]: Frequency of comorbid triggers for asthma among the study participants, [B]: Controller history and asthma control status among the study participants

\section{DISCUSSION}

\section{Asthma and socio-demographic characters}

In Egypt, Bronchial asthma was prevalent among schoolchildren in El-Fayoum city [district] at 6.3\% [20]. Most of the pitfalls of asthma treatment are under diagnosis and under treatment in childhood asthma. The combination of a patient's medical history with an understanding of their asthma symptoms is now considered the cornerstone of asthma diagnosis [21].

The current study revealed that there was no significant variation in the total $\mathrm{QOL}$ scores based on age, gender, or place of residence. On the other hand, Symptoms PAQLQ scores in urban asthmatic children were significantly higher than the rural asthmatic children. This was consistent with earlier research [15, 22], which indicated that there was no significant difference between male and female participants in terms of overall age, different categories of pediatric QoL scores [symptoms, activity, and emotional scores], and all caregiver ratings [activity and emotional scores].

Another Jordanian research, on the other hand, showed that the age of older patients was associated with greater QOL [23]. This might be attributed to cognitive and emotional developmental variations in acquiring the necessary knowledge; teenagers are able to deal with the disease's challenge differently than younger children.

According to Reichenberg and Broberg [19], there was little difference in the overall score of activities, symptoms, and emotions between boys and girls. A Jordanian research, on the other hand, found that females had lower overall and three domain PAQLQ scores than males [23]. Asthma limits 
girls' movements and has an emotional impact on them more than it does on boys. Parents may be more concerned with their sons' minimal activity unlike females beside; boys are expected to be more involved outside the home than girls in conservative cultures.

The current study showed that the parents of the majority of our participants [77\%] had belonged to middle and low socioeconomic classes; coincided with the study conducted by Elshazly et al. [15]. This hospital-based study was carried out in the governorate of Damietta's major governmental tertiary hospitals, which have the best medical care for asthmatic children. Furthermore, the bulk of people from higher socioeconomic classes receive their medical care mostly from the private sector. The majority of the patients surveyed lived in rural areas [69.5\%] relative to urban areas [30.5\%]. It agreed with the findings of Abd Elmoneim et al. [24], who estimated that [63.5\%] of his surveyed asthmatic children came from rural areas, and another survey showed the same [87.1\%] [7]. It is possible that this is due to a shortage of medical services in rural areas, and people tended to go to more advanced hospitals.

Our study clarified that the higher the socioeconomic class levels the higher the PAQLQ scores. These results came in agree with previous studies $[25,26]$ which concluded that; children from poor and extremely low economic classes have lower QOL scores. Previously, high family income has a positive impact on QOL scores ${ }^{[27]}$. This reflects the effect of affordability of health care costs on patients QOL. Furthermore, a high SES provides reassurance to family members and adds to their psychological well-being.

\section{Asthma control and comorbid conditions}

Our study revealed that only [23.5\%] of asthmatic children showed appropriate asthma control. It was coincided with Banjari et al. ${ }^{[28]}$ who reported that only [16\%] control rate in his studied asthmatic children. It was different from previous study who reported that [40.6\%] of asthmatic children had controlled level of asthma [29].

Asthma in children that is uncontrolled can be caused by a variety of factors such as age, male gender, education level of parent, exposure to indoor smoking, pet ownership, lack of usage of short-acting B2-agonists, poor inhaler technique and co-existing illnesses ${ }^{[28]}$.

Our study found that GER, allergic rhinitis, and a positive family history of asthma were all negatively associated with asthma control status. Kim et al. [30] discovered that asthma increased the likelihood of GERD, and GERD increased the chance of asthma. Asthmatic children were 1.36 times more likely to develop GERD than the general population. In the same setting, the most prevalent pediatric atopic diseases include atopic dermatitis $[A D]$, allergic rhinitis $[A R]$, and bronchial asthma [BA] [31].

\section{Asthma control and pediatric asthma quality of life}

The current study clarified the positive effect of asthma control on PAQLQ total and all domains scores. Controlled asthma is related to higher QOL scores in asthmatic kids. Poorly controlled asthma is associated with repeated symptoms, activity limitations, and anxiety over asthma attacks. This corresponds to prior studies in Egypt and other nations $[15,32,33,34]$.

The patient's fear of exacerbating their asthma illustrates their reluctance to engage in physical exercise or continue their education productivity and attendance. It stands to reason why these children might stop any activities that could initiate an asthma attack.

Other investigators have observed that uncontrolled asthmatic children had a somewhat lower activity restriction score, symptoms score, and overall asthmatic score than controlled asthmatic children [25, 34].

This implies that the degree of asthma management, particularly physical activity such as sports and workouts, has an influence on health-related quality of life [HRQOL]. It also implies that an asthmatic youngster needed both medical care and mental counseling. Elnady et al. ${ }^{[29]}$ noted in the same context that there was no significant difference in the emotional function score between the two asthmatic groups [controlled and uncontrolled].

\section{Possible predictors of Pediatric Asthma Quality of Life}

In this study, PAQLQ as a dependent variable and other potential independent predictors were subjected to a stepwise linear regression analysis. Low socioeconomic status, inadequate asthma control, and a history of taking controller drugs were all shown to be important predictors of low pediatric quality of life. Another Egyptian study showed that parental smoking, systemic steroid usage, difficulty getting medicines, asthma-related hospitalization, and degree of asthma control were predictors of the total PAQLQ score for children with bronchial asthma ${ }^{[7]}$.

In a prior study, the child's age and gender were discovered to be among the primary independent predictors of asthmatic children's QOL [9].

While gender [higher scores for boys] and exposure to passive smoking in the household were significant predictors of asthmatic teenage quality of life [higher scores for those not exposed] [35]. 
Another study conducted in the United States found that the following clinical and familial factors were strongly related with the HRQL result as measured by the PAQLQ: The length of nocturnal symptoms, the number of visits to the primary care physician, the quality of control, and family losses and transitions ${ }^{[36]}$.

However, quality as a concept seems to resist measurement. Although certain dimensions of quality of life are clearly observable, others are clearly not. As health related quality of life [HRQL] instruments' are perfected, the struggle is to clearly define the principles and assumptions that guide their quantitative assessment. HRQL studies that use well-designed qualitative approaches can also be performed.

\section{CONCLUSION}

Children with asthma tend to have a poorer quality of life. PAQOL was markedly poorer among children with low socioeconomic standards and uncontrolled asthmatics especially whom spent a lot on controller medications. So we recommend:

1. Special interest should be directed towards the control of the comorbid conditions with asthma.

2. Psychological support of uncontrolled asthmatic children to avoid psychic trauma and feeling of inferiority.

3. Encourage set up "asthma day" like "diabetes day" to make peer support between asthmatic children.

4. Chest medicine professionals should seize the opportunity to plan for educational programmers and counseling sessions for young pediatricians and chest clinicians on written self-management action plans construction.

5. Further research is needed to explain the observed triggers for decrease in PAQOL scores among asthmatic children on wide scale.

Financial and Non-financial Relationships and Activities of Interest

None

\section{REFERENCES}

1. Global Initiative for Asthma [GINA]. Global Strategy for Asthma Management and Prevention. Available at: https://ginasthmaorg/ wp-content/uploads/2018/04/wms-GINA2018-report-V1.3-002.pdf] accessed in May 15, 2021.

2. Alahmadi TS, Banjari MA, Alharbi AS. The prevalence of childhood asthma in Saudi Arabia. Int J Pediatr Adolesc Med. 2019 Jun 1;6[2]:74-7. DOI: 10.1016/j.ijpam.2019.02.004.

3. Zedan M, Settin A, Farag M, Ezz-Elregal M, Osman E, Fouda A. Prevalence of bronchial asthma among Egyptian school children. Egypt J Bronchol. 2009 Dec;3[2]:124-30. DOl: 10.4103/1110-2098.178992.

4. World Health Organization. Asthma fact sheet. 2019. [Available via http://www.who.int/healthinfo/global_burden_disease/ Global HealthRisks_report_full.pdf] Visited in 3/5/2021.

5. Ghaffari J, Aarabi M. The prevalence of pediatric asthma in the Islamic Republic of Iran: A systematic review and metaanalysis. J Pediatr Rev. 2013 Jan 1;1[1]:2-11.

6. Abdel-Baseer KA, Hammad EE, Qubaisy H, Naser MA, Ahmed AA, Said AM. Some epidemiological aspects of bronchial asthma in children in Qena Governorate, Egypt. Immunome Res. 2017;13[3]:1-5. DOI: 10.4172/1745-7580.1000138.

7. Al-Gewely MS, El-Hosseiny M, Abou Elezz NF, El-Ghoneimy DH, Hassan AM. Health-related quality of life in childhood bronchial asthma. Egypt J Pediatr Allergy Immunol. 2013;11[2]:83-93.

8. Post M. Definitions of quality of life: what has happened and how to move on. Top Spinal Cord Inj Rehabil. 2014;20[3]:16780. DOI: $10.1310 / \mathrm{sci} 2003-167$.

9. Annett RD, Bender BG, Lapidus J, DuHamel TR, Lincoln A. Predicting children's quality of life in an asthma clinical trial: what do children's reports tell us?. J Pediatr. 2001 Dec 1;139[6]:854-61. DOI: 10.1067/mpd.2001.119444.

10. Rand CS, Butz AM, Kolodner K, Huss K, Eggleston P, Malveaux F. Emergency department visits by urban African American children with asthma. J Allergy Clin Immunol. 2000 Jan 1;105[1]:83-90. DOI: 10.1016/S0091-6749[00]90182-9.

11. Dardas LA, Ahmad MM. Quality of life among parents of children with autistic disorder: A sample from the Arab world. Res Dev Disabil. 2014 Feb 1;35[2]:278-87. DOI: 10.1016/j.ridd. 2013.10.029.

12. Erickson SR, Munzenberger PJ, Plante MJ, Kirking DM, Hurwitz ME, Vanuya RZ. Influence of sociodemographics on the health-related quality of life of pediatric patients with asthma and their caregivers. J Asthma. 2002 Jan 1;39[2]:10717. DOI: 10.1081/JAS-120002192.

13. Tauler E, Vilagut G, Grau G, González A, Sánchez E, Figueras $G$, et al. The Spanish version of the paediatric asthma quality of life questionnaire [PAQLQ]: metric characteristics and equivalence with the original version. Qual Life Res. 2001 Jan;10[1]:81-91. DOI: 10.1023/A:1016622519987.

14. Oga T, Nishimura K, Tsukino M, Sato S, Hajiro T, Mishima M. Comparison of the responsiveness of different disease-specific health status measures in patients with asthma. Chest. 2002 
15. Elshazly HM, El Mahalawy II, Gabr HM, Abd El Naby SA, Elzoghby EE. Quality of life among asthmatic children attending the Outpatient Clinic in Menoufia University Hospital. Menouf Med J. 2015 Apr 1;28[2]:442. DOI:10.4103/1110-2098. 163899

16. Jia CE, Zhang HP, Lv $Y$, Liang $R$, Jiang $Y Q$, Powell $H$, et al. The Asthma Control Test and Asthma Control Questionnaire for assessing asthma control: systematic review and metaanalysis. J Allergy Clin Immunol. 2013;131[3]:695-703. DOI: 10.1016/j.jaci.2012.08.023.

17. Juniper EF, Guyatt GH, Feeny DH, Ferrie PJ, Griffith LE, Townsend M. Measuring quality of life in children with asthma. Qual Life Res. 1996;5[1]:35-46. DOI: 10.1007/BF00435967.

18. Labrell F, Costa HC, Perdry H, Dellatolas G. The Time Knowledge Questionnaire for children. Heliyon. 2020 Feb 1;6[2]:e03331. DOI: 10.1016/j.heliyon.2020.e03331.

19. Reichenberg K, Broberg AG. Quality of life in childhood asthma: use of the Paediatric Asthma Quality of Life Questionnaire in a Swedish sample of children 7 to 9 years old. Acta Paediatr. 2000 Aug;89[8]:989-95. DOI: 10.1080/ 080352500750043495.

20. Ahmad EE, Kamel AS, Amin SA, Hashem AE. Epidemiology of Childhood Asthma in Fayoum City (District) Egypt. Pharm Biosci J. 2016:67-75. DOI: 10.20510/UKJPB/4//4/112413.

21. Becker AB, Abrams EM. Asthma guidelines: the Global Initiative for Asthma in relation to national guidelines. Curr Opin Allergy Clin Immunol. 2017 Apr 1;17[2]:99-103. DOI:10.1097/ ACl.0000000000000346

22. Hallit S, Raherison C, Waked M, Hallit R, Layoun N, Salameh P. Validation of the mini pediatric asthma quality of life questionnaire and identification of risk factors affecting quality of life among Lebanese children. J Asthma. 2019 Feb 1;56[2]:200-10. DOI: 10.1080/02770903.2018.1441417.

23. Al-Akour N, Khader YS. Quality of life in Jordanian children with asthma. Int J Nurs Pract. 2008 Dec;14[6]:418-26. DOI: 10.1111/j.1440-172X.2008.00715.x.

24. Abd Elmoneim A, Hassan IA, Abd Elnaby A, Abou Elmagd A. Epidemiology and outcome of childhood asthma: a clinical study in an Egyptian university medical centre. East Mediterr Health J. 2013 Jun 1;19[6]:520-6. PMID: 24975180

25. El-Gendi SD, Mostafa SA, Walli MH, Hassan OM, El-Awady MA, Omar DI. Assessment of health-related quality of life in asthmatic children and their caregivers. Int J Med Sci Public Health. 2017 Apr 1;6[4]:798-806. DOI: 10.5455/ijmsph.2017. 0638206122016.

26. de Souza PG, Sant'Anna CC, Maria de Fátima B. Quality of life in children with asthma in Rio de Janeiro, Brazil. Ind J Pediatr.
27. Olson LM, Lara M, Pat Frintner M. Measuring health status and quality of life for US children: relationship to race, ethnicity, and income status. Ambul Pediatr. 2004 Jul-Aug;4(4 Suppl):37786. DOI: $10.1367 /$ A03-156.1.

28. Banjari M, Kano Y, Almadani S, Basakran A, Al-Hindi M, Alahmadi T. The Relation between Asthma Control and Quality of Life in Children. Int J Pediatr. 2018 Jul 3;2018:6517329. DOI: $10.1155 / 2018 / 6517329$.

29. Elnady HG, Sherif LS, Sabry RN, Zeid DA, Atta H, Hassanain $\mathrm{Al}$, et al. Relation of asthma control with quality of life among a sample of Egyptian asthmatic school children. Open Access Maced J Med Sci. 2019 Sep 15;7[17]:2780. DOI: 10.3889/oamjms.2019.649.

30. Kim SY, Kim HR, Min C, Oh DJ, Park B, Choi HG. Bidirectional association between GERD and asthma in children: two longitudinal follow-up studies using a national sample cohort. Pediatr Res. 2020 Aug;88[2]:320-4. DOI: 10.1038/s41390-0200749-1.

31. Rasheed Z, Zedan K, Saif GB, Salama RH, Salem T, Ahmed $A A$, et al. Markers of atopic dermatitis, allergic rhinitis and bronchial asthma in pediatric patients: correlation with filaggrin, eosinophil major basic protein and immunoglobulin E. Clin Mol Allergy. 2018 Dec;16[1]:1-9. DOI: 10.1186/s12948-018-0102-y.

32. Dean BB, Calimlim BC, Sacco P, Aguilar D, Maykut R, Tinkelman D. Uncontrolled asthma: assessing quality of life and productivity of children and their caregivers using a crosssectional Internet-based survey. Health Qual Life Outcomes. 2010 Sep 8;8:96. DOI: 10.1186/1477-7525-8-96.

33. Ayuk AC, Oguonu T, Ikefuna AN, Ibe BC. Asthma control and quality of life in school- age children in Enugu south east, Nigeria. Niger Postgrad Med J. 2014 Jun;21(2):160-4. PMID: 25126871 .

34. Furtado PR, Maciel ÁC, Barbosa RR, da Silva AA, de Freitas $\mathrm{DA}$, de Mendonça KM. Association between quality of life, severity of asthma, sleep disorders and exercise capacity in children with asthma: a cross-sectional study. Braz J Phys Ther. 2019;23(1):12-18. DOI: 10.1016/j.bjpt.2018.08.010.

35. Svavarsdottir EK, Burkhart PV, Rayens MK, Orlygsdottir B, Oakley MG. Icelandic and United States families of adolescents with asthma: predictors of health-related quality of life from the parents' perspective. J Clin Nurs. 2011;20[12]:267-273. DOI:10.1111/j.1365-2702.2009.03110.x.

36. Walker VG. Exploration of the Influence of Factors Identified in the Literature on School-aged Children's Emotional Responses to Asthma. J Pediatr Nurs. 2017 Mar-Apr; 33:54-62. DOI: 10.1016/j.pedn.2016.11.008. 


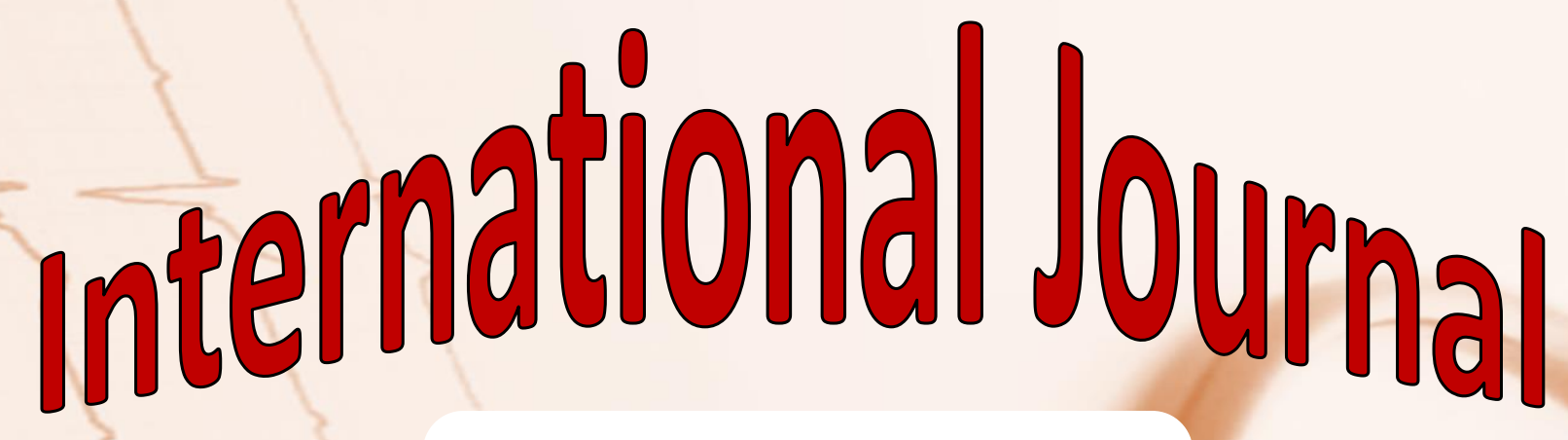

https://ijma.journals.ekb.eg/ Print ISSN: 2636-4174 Online ISSN: 2682-3780

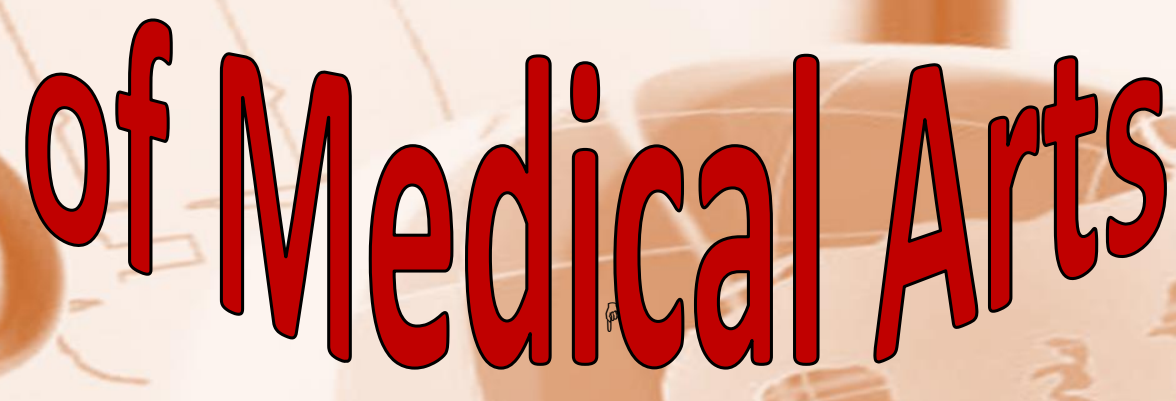

